\title{
Understanding the Long Term Ecosystem Stability of a Fen Mire by Analyzing Subsurface Geology, Eco-Hydrology and Nutrient Stoichiometry - Case Study of the Rospuda Valley (NE Poland)
}

\author{
Ewa Jabłońska - Tomasz Falkowski • Jarosław Chormański • Filip Jarzombkowski • \\ Stanisław Klosowski • Tomasz Okruszko • Pawel Pawlikowski • Martin Theuerkauf • \\ Martin J. Wassen • Wiktor Kotowski
}

Received: 9 May 2013 / Accepted: 8 May 2014 / Published online: 6 June 2014

(C) The Author(s) 2014. This article is published with open access at Springerlink.com

\begin{abstract}
We explored the background of differences in long-term stability between two parts in an undisturbed mire system (Rospuda fen, NE Poland). We re-constructed the Holocene history of the mire and compared it with current vegetation, water level dynamics, water chemistry and nutrient availability in two basins: A, where the mire terrestrialised a deep gyttja-filled lake, and B, where peatland developed directly on fluvial sands. The current vegetation of sedgemoss fens was described in 10 relevés from each basin, groundwater was sampled from piezometers and analysed
\end{abstract}

E. Jabłońska $(\bowtie) \cdot$ S. Kłosowski $\cdot$ P. Pawlikowski $\cdot$ W. Kotowski Department of Plant Ecology and Environmental Conservation, Faculty of Biology, University of Warsaw, ul. Żwirki i Wigury 101, 02-089 Warsaw, Poland

e-mail: e.jablonska@uw.edu.pl

T. Falkowski

Department of Geotechnical Engineering, Warsaw University of Life Sciences, ul. Nowoursynowska 159, 02-787 Warsaw, Poland

J. Chormański · T. Okruszko

Department of Hydraulic Engineering, Warsaw University of Life

Sciences, ul. Nowoursynowska 159, 02-787 Warsaw, Poland

F. Jarzombkowski

Department of Nature Protection in Rural Areas, Institute of Technology and Life Sciences, 05-090 Al. Hrabska 3, Falenty, Poland

\section{Theuerkauf}

Institute of Botany and Landscape Ecology, Ernst Moritz Arndt University of Greifswald, Grimmer Straße 88, 17-489 Greifswald, Germany

\section{J. Wassen}

Environmental Sciences, Copernicus Institute of Sustainable Development, Faculty of Geosciences, Utrecht University, PO Box 80115, 3508 TC Utrecht, The Netherlands for major ions, while its relative water level was recorded during three years. $\mathrm{N}$ and $\mathrm{P}$ content was measured in above ground vascular plant samples collected within the relevés. Fens in basin A were stable in the past, whereas fens in basin B switched between open and wooded or reed-dominated phases. In basin B, where trees are more abundant, we found higher water fluctuations, occurrence of river floods and a higher N:P ratio than in basin A. Our interpretation follows that the subsurface geology of fen basin may govern mire stability by determining its hydrological-buffering capacity, which may affect N:P ratios. Our results suggest that $\mathrm{P}-$ limited fens are more vulnerable for changes in water level.

Keywords Rich fen · Mire Stability · Brown Moss-small Sedge Vegetation · Palaeobotany · Water level Dynamics . Landscape $\cdot \mathrm{N}: \mathrm{P}$ Ratio

\section{Introduction}

Ecosystem stability depends on several other ecosystem properties, such as resistance, resilience or a number of possible alternative stable states, as well as upon various external factors (Ives and Carpenter 2007). There is a growing evidence that mire ecosystems are characterised by quasi-stable aequilibrium states, which are resilient to change at some level of perturbation but shift to new states at higher levels of disturbance (Scheffer et al 2001, Bridgham et al 2008, Dise 2009, Granath et al 2010). Such shifts include transitions from a peat accumulating mire into a peatland that does not sequester carbon anymore, or a groundwater-fed fen into a bog (e.g. Almquist-Jacobson and Foster 1995; Hughes and Barber 2004; Beaulieu-Audy et al 2009, Kooijman 2012) or the 
reverse (Hájková et al 2012) but also switches between an open (herbaceous) fen and a wooded fen (e.g. Żurek et al 2002). Transitions between these alternative states imply drastic changes in species assemblages, as well as in key ecosystem functions, such as productivity, peat formation and carbon sequestration (Bridgham et al 2008, Dise 2009). Specifically, expansion of trees on open mires may, through positive feedbacks of enhanced evapotranspiration, decrease water saturation in surface peat layers, slowing down or completely ceasing peat formation (Succow and Joosten 2001). In recent history, human-induced drainage and eutrophication have been the most important causes of the shift of herbaceous fen communities to scrubs or forests, but palaeoecological records document also natural shifts, driven by climatic fluctuations or geomorphological changes in the landscape (e.g. Żurek et al 2002).

Mechanisms of long-term stability in peatlands have been mainly studied in rainwater-fed bogs (e.g. Belyea and Baird 2006, Eppinga et al 2009, Morris et al 2011), whereas such analyses are scarce in groundwater-fed fens (but see e.g., Michaelis 2002), which belong to the most threatened mire types worldwide, having vanished from agricultural drainage, landscape transformation and eutrophication (Van Diggelen et al 2006). Relating long-term ecosystem dynamics of fens to their local geological settings and internal ecological processes should help to improve predictions about their future stability and propose more effective strategies of their long-term conservation.

There is quite a large body of knowledge about which internal and external factors affect ecological processes in fens, likely determining their stability. At the landscape scale, fen ecosystems depend upon the hydrological situation in their catchments. Large catchments and undisturbed groundwater flows through aquifers allow constant and abundant water supply to fens (Grootjans et al 2006). Another important factor is the subsurface geology of the mire, which may determine its buffering capacity against changes in water supply. Specifically, percolation fens i.e. fens in which water percolates through the peat layer in lateral and/or upward direction, may develop under two contrasting geologic conditions: on top of terrestrialisation mires or directly onto mineral ground (Succow and Joosten 2001). This difference likely impacts their future stability. The thick layer of gyttja, characterised by low water permeability, seals the bottom of the peatland and concentrates the ground water flow within the peat body, thus ensuring more stable hydrological conditions for continuous peat formation. Peatlands formed under such circumstances have a higher oscillation capacity thus are more effectively buffering changes in discharge and further stabilizing mire growth.

The biogeochemical preconditions of fen stability are related to the availability of limiting nutrients, especially nitrogen $(\mathrm{N})$ and phosphorous $(\mathrm{P})$. Their amount in fen pore water is controlled in first instance by (hydrology-dependent) peat mineralisation rates (Olde Venterink et al 2003) and external input, e.g. from floodwater or anthropogenic deposition (Olde Venterink et al 2003, 2009). Secondly, the availability of P can be reduced due to precipitation by calcium $(\mathrm{Ca})$ ions or iron (Fe) hydroxides, the latter mechanisms being enhanced by higher redox potential (Grootjans et al 2006). In effect, sedge-moss fens may develop and exist under different $\mathrm{N}: \mathrm{P}$ ratios, with primary productivity being limited by either of these elements (Van Duren and Pegtel 2000, Wassen and Olde Venterink 2006, Pawlikowski et al 2013). According to the recent study by Pawlikowski et al (2013), N and P-limited fens differ in species composition.

Although we know a lot about the magnitude of processes controlling the development and persistence of fens, the scarcity of studies linking long-term palaeo-ecological reconstructions with landscape eco-hydrology and present vegetation processes makes it difficult to assess the relative importance of various factors for long-term stability of fen mires. Given the rareness of undisturbed percolation fens, most research on ecohydrology and development of this mire type focused on transformed mires, which hampers conclusions on the preconditions of natural mire development (e.g. Michaelis 2002). Undisturbed percolation mires have recently been found and studied in Siberia (Schipper et al 2007) and China (Schröder et al 2007). The Rospuda fen in north-east Poland is one of the few remaining well-preserved percolation mires in temperate Europe (cf. Jabłońska et al 2011). Our analysis of this system, presented here, aims to contribute knowledge about ecological relations and feedbacks controlling fen stability.

In the Rospuda valley, two mire parts differ considerably with respect to subsurface geological settings and long-term vegetation stability. By jointly analysing sub-fossil and present plant communities, we attempt to develop a processrelated interpretation of the different behaviour of fens in these two mire parts, based on geological, eco-hydrological and bio-geochemical mechanisms of their functioning.

\section{Study Area}

The Rospuda river valley mire is located in the young-glacial landscape of NE Poland (Fig. 1), in the vicinity of Augustów (N 53 50' 49.98”, E 22 59' 8.72”).

The mire developed in a deep sub-glacial channel cutting through two high plains. The pre-Quaternary crystalline basement was marked by dislocation zones (tectonic faults) here, which could have been activated all over the Pleistocene under the glacier weight (Ber 2000), developing diversified relief for depositing glacial sediments. Anther process, which could have also influenced formation of subglacial channels (including the one of Rospuda), is the upheaval of the ground surface 


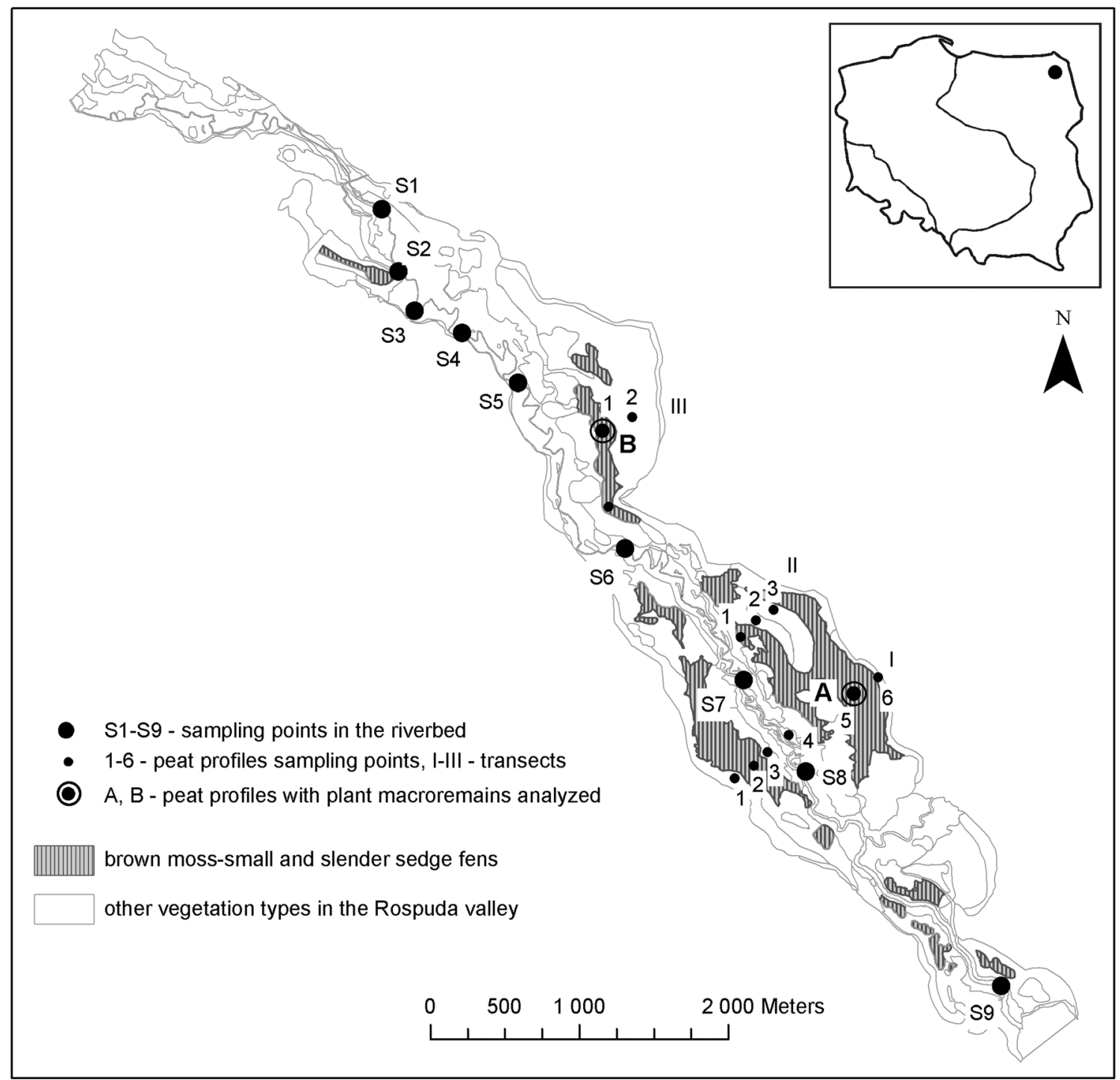

Fig. 1 Study area and location of sampling points (for more detailed vegetation map, see Jabłońska et al 2011)

after the glacier retreat. The glacial deposits in the region of the Rospuda catchment are approximately 140-200 m thick (Ber 2000) and include layers of different age and character: sandy clays with fragments of crystalline rock, boulder clays, lacustrine silts and loams, fluviogenic sands and gravels (Ber 2000). Foundations of the present geomorphology of the area were shaped during transgression and regression of the last (Vistulian) glaciation (Ber 2000). Evorsive depressions within the subglacial channel of Rospuda filled in with ice during deglaciation (Wysocka 1992). Next, shallow lakes on ice were formed which during the Late Glacial were gradually filled with mineral and organic deposits. The ice-lenses lying at the bottom of lakes protected those hollows from being fully filled with deposits in later times when the area was periglacial zone where a large supply of eroded material was carried by the rivers. The final melting of ice led to a start of contemporary deposition type. Rospuda river valley is a polygenetic landform, with post-lake parts connected by stretches of river gaps.

Our study was conducted on a mire in the southern part of the Rospuda valley. The area of the whole mire is approximately 670 ha, of which c. 100 ha is covered with open brown moss-small sedge vegetation. Peat deposits are c. 1 to $3 \mathrm{~m}$ deep, partly lying on deep gyttja layers. According to our estimates, the direct infiltration area of the mire is c. 5 times as large as the mire itself (catchments of tributary streams of Rospuda and the upper part of the Rospuda river were excluded in this estimate). The catchment is covered by pine forests extensively managed for forestry. The mire has never been drained. Until the 1970s locally hay cutting (by hand) was practiced by the local farmers.

We investigated two basins of the brown moss-small sedge vegetation in the Rospuda valley (Fig. 1; for more detailed description of the vegetation, see Jabłońska et al 2011). The 
lower basin (A) encompasses the main area of open small sedge-brown moss vegetation in the valley. The upper basin (B) shows a wider zone of woodlands and a narrower zone of sedge-moss fens; the latter having a sparse cover of shrubs and trees.

\section{Methods}

To characterise subsurface geology, nine deep geological cores were taken in the riverbed (Fig. 1-S1-S9). To describe peat stratigraphy, 11 peat cores were taken along three transects using an Instorf (Eijkelkamp Agrisearch Equipment, Giesbeek, NL) coring device (Fig. 1).

Plant macro-remains were analyzed macroscopically in all cores in the field and microscopically in two peat cores (one from each area, Fig. 1). Peat samples of $30 \mathrm{~cm}^{3}$ were collected every $10 \mathrm{~cm}$. Samples were boiled for $5 \mathrm{mi}-$ nutes in $10 \% \mathrm{KOH}$ (Tobolski 2000) and sieved using $1 \mathrm{~mm}$, $0.5 \mathrm{~mm}$ and $0.25 \mathrm{~mm}$ mesh size. The volume of each fraction was estimated. Determination follows Bertsch (1941); Nilsson and Hjelmquist (1967); Berggren (1969); Grosse-Brauckman (1972); Beijerink (1976); Smith (1980); Grosse-Brauckman and Streitz (1992); Tobolski (2000); Michaelis (2001). The diagrams were drawn using the C2 software (Juggins 2003). No objective dating of samples was done in this project, therefore we do not refer to an absolute time scale, restricting our interpretation to the succession and relative stability of sub-fossil plant communities.

Water level was measured in 2 piezometers installed close to the peat sampling points A and B. Filters of the piezometers were $20 \mathrm{~cm}$ long and extend from $1.3 \mathrm{~m}$ to $1.5 \mathrm{~m}$ depth in the peat. Measurements were continuously registered during 3 years (2007-2009) in $6 \mathrm{~h}$ intervals, using MiniDiver groundwater data loggers (Eijkelkamp Agrisearch Equipment, Giesbeek, NL). Piezometers were levelled in March 2007, March 2008 and June 2009 using GPS-RTK technique by set of two dual-frequency (L1/L2) GPS receivers TOPCON Legacy E with the vertical accuracy of 2-3 cm (Chormański 2008). Diver readings were transformed from absolute to relative values by subtracting the absolute values of the ground level (for readings from 2007 the value from March 2007, for readings from 2008 the value from March 2008, etc.).

Another 9 piezometers were installed to sample groundwater for chemical analyses. Filter part of each piezometer was $20 \mathrm{~cm}$ long and consisted of textile mesh. Five of them, $3 \mathrm{~m}-$ deep, were installed along transect I (area A) with filters reaching the bottom of the peat layer, just above the gyttja layer. Four, c. $2.5 \mathrm{~m}$-deep, piezometers were installed along transect III (area B), three of them with filters placed at the bottom of the peat layer and one piezometer with a filter placed in the sand and gravel layer just beneath the peat.
Water was sampled in May, July and September 2007 from 9 piezometers and taken from surface water in 5 localities along the river (evenly distributed between points S1 and S9). Before sampling, piezometers were emptied and left to re-fill for several hours. Samples were filtered with a paper filter a few hours after collecting them, then samples for $\mathrm{NO}_{3}{ }^{-}, \mathrm{NH}_{4}{ }^{+}, \mathrm{PO}_{4}{ }^{3-}$ and $\mathrm{Fe}_{\text {total }}$ analyses were conserved by adding $1 \mathrm{ml} \mathrm{H}_{2} \mathrm{SO}_{4}$ per 11 of the sample. In the laboratory, water samples were analysed for: $\mathrm{PO}_{4}{ }^{3-}$ spectrophotometrically by a molybdate method, $\mathrm{NO}_{3}{ }^{-}$spectrophotometrically with phenoldisulphonic acid, $\mathrm{NH}_{4}^{+}$spectrophotometrically by a Nessler's method, $\mathrm{SO}_{4}{ }^{2-}$ spectrophotometrically by the a nephelometric method, total Fe spectrophotometrically by the a rhodanate method (DR5000, HACH LANGE, DE), carbonate hardness by the Warthy-Pfeifer method, $\mathrm{Mg}^{2+}$ with atomic absorption spectrometer (UNICAM 939, Chris Hillseth Enterprises, CA), $\mathrm{Ca}^{2+}$ with a flame spectrophotometer (FLAPHO 4, Carl Zeiss Jena, DE).

Spatial differences of the chemical composition of water was analysed by PCA in CANOCO for Windows Version 4.0 (Ter Braak and Šmilauer 1998). For this, we calculated means from three measurements (May, July, September) for each location, for all chemical parameters. Information about the origin of each sample (area A, area B, river) was used as a supplementary variable.

Twenty relevés (10 in each area) of $5 \times 5$ m were recorded in June-July 2008 along transects I and III, within brown moss-sedge fen vegetation. The Braun-Blanquet (1951) scale was applied. Living (green) parts of vascular plants were collected within each relevé from $50 \mathrm{~cm} \times 50 \mathrm{~cm}$ plots in August 2008. Samples were dried in $70{ }^{\circ} \mathrm{C}$ and weighed. A sample of $0.2-0.3 \mathrm{~g}$ was taken at random from the ground plant material and digested according to Kjeldahl (Allen 1989). N-concentration in the digests was analysed colorimetrically using a Skalar Auto-Analyser, $\mathrm{P}$ and $\mathrm{K}$-concentrations by means of an Inductively Coupled Plasma technique (ICP). Means and $95 \%$ confidence intervals (CI) were calculated in two-sided $\mathrm{t}$-test in $\mathrm{R}$ (The $\mathrm{R}$ development Team 2010).

The variability of species composition of brown mosssedge fen vegetation in areas A and B was analysed by DCA in CANOCO for Windows Version 4.0 (Ter Braak and Šmilauer 1998).

\section{Results}

Mire formation in the lower basin (area A) started after terrestrialisation of a deep glacial lake (the gyttja layer was over $17 \mathrm{~m}$ in the deepest coring). In the upper basin (area B), mire growth started directly on a sandy alluvial delta (Fig. 2), which starts between profiles S3 and S4. The river has built 


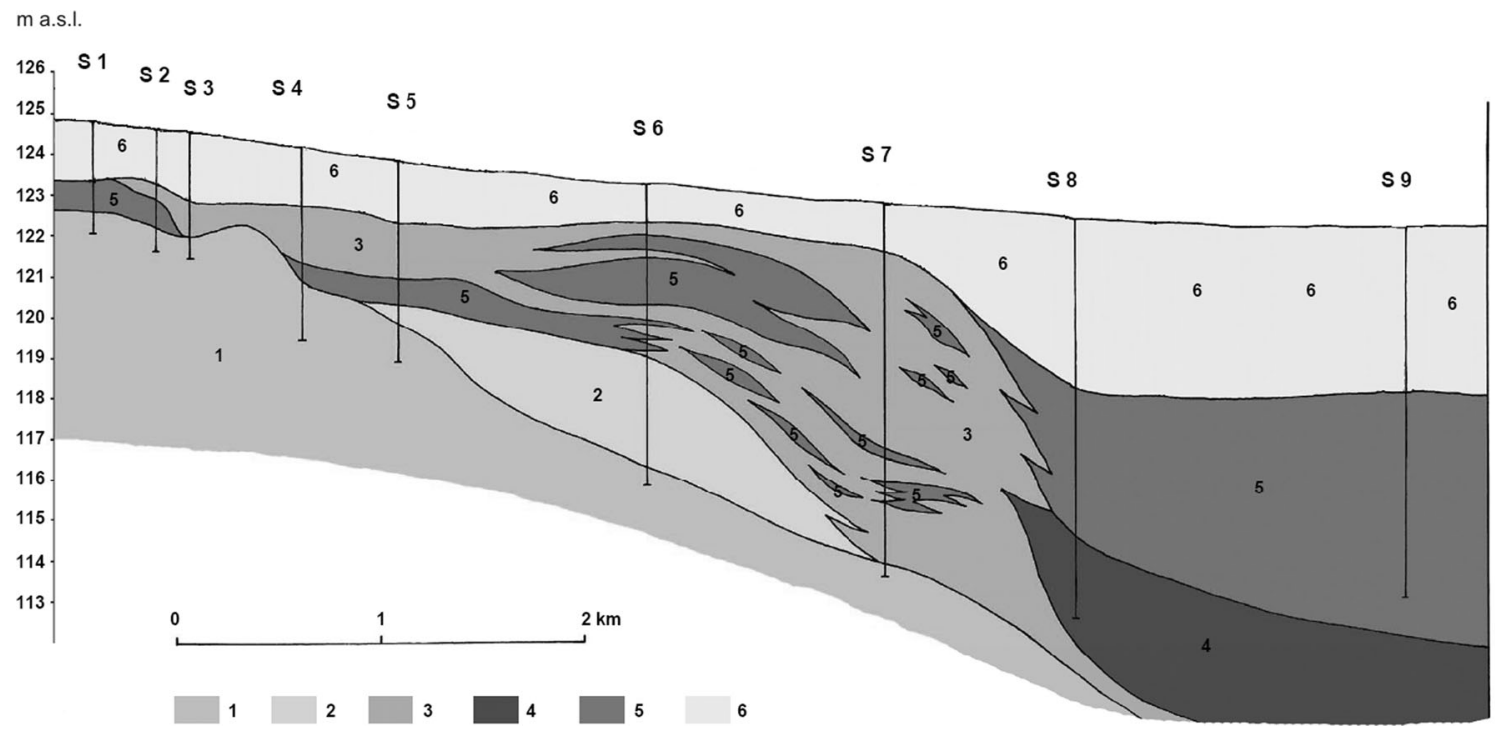

Fig. 2 Geological cross-section of the Rospuda valley along the riverbed; 1 - fluvioglacial sand/gravel deposits, 2 - fine/medium sand, 3 - fine/medium sand with intercalations of aggradate sandy mud, 4 - gyttja, 5 - peat and aggradate peaty mud, 6 - peat outside the riverbed (border between 5 and 6 is schematic)

the delta within a thaw lake, in which lacustrine deposits were accumulated at the same time. The delta declines starting from the profile $\mathrm{S} 7$ (Fig. 2).

The macrofossil composition of both profiles differs sharply. In the lower basin (profile A) two zones were distinguished ( $\mathrm{m}$ and $\mathrm{n}$; Fig. 3 ). The presence of
Najas marina leaves in the lower part of zone $\mathrm{m}$ indicates shallow water. Macrofossils of Thelypteris palustris, Phragmites australis, Menyanthes trifoliata and Carex sp. found on top of that indicate at the formation of a floating mat and the terrestrialisation of the lake. Betula sp. seeds may indicate the existence of birch trees or shrubs. The absence of

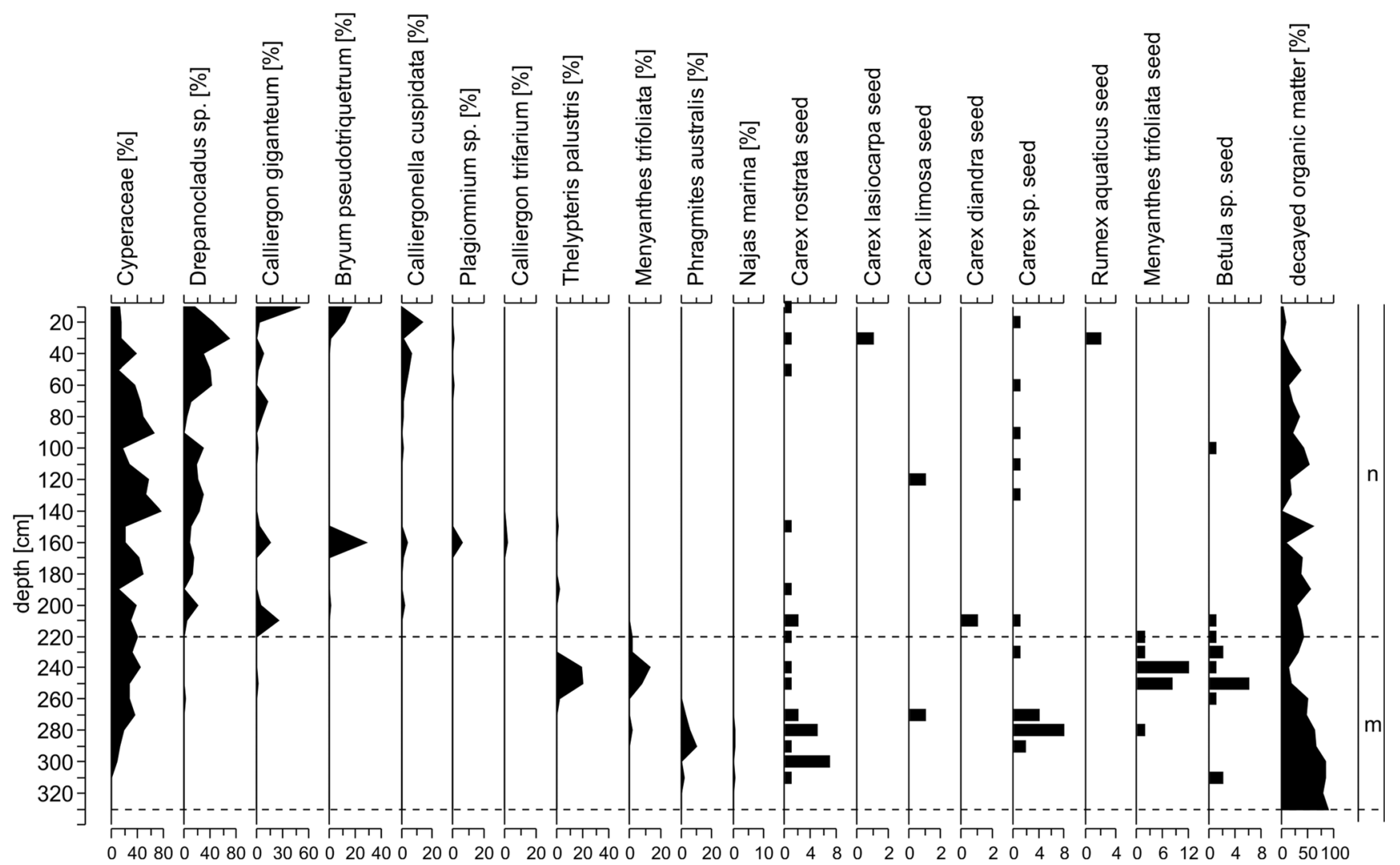

Fig. 3 Main plant macroremains in the profile A (lower basin) 
wood suggests that these seeds did not originate from the site itself but have been blown in by wind from the neighbouring upland. The approximately 3 times thicker upper zone $\mathrm{n}$ is dominated by remnants of Cyperaceae and brown mosses, representing the presence of a brown moss-small sedge fen vegetation. In the upper basin (profile $B$ ), we distinguished four zones (a, b, c, d; Fig. 4). The lower peat layers (zone a and b) contain wood, fragments of leaves of broadleaf trees and seeds of Alnus glutinosa and Betula sp. Carex seeds are abundant. The mire may have started to develop in an alluvial forest. The presence of charcoal in zone $b$ points to the disturbance by fire. Zone $\mathrm{c}$ is dominated by macrofossils of Phragmites australis and Cyperaceae, indicating tall sedge fen vegetation. The uppermost zone $d$ is dominated by brown mosses, representing the brown moss-small sedge vegetation. Results of peat profile analyses along transects IIII and results of analyses of deep geological cores in the riverbed (S1-S9) were extrapolated to the whole mire (Fig. 5). The interpretation of the most likely spatial pattern of the mire development during the Holocene is presented in Fig. 6.

The hydrological conditions of the two analysed mire basins were different during the 3-year observation period. Water level was more stable in the lower basin, on average reaching $1.8 \mathrm{~cm}$ above the peat surface. Only short (a few days-long) spring peaks of water table to more than $10 \mathrm{~cm}$ above ground level occurred here (Fig. 7). In contrast, the upper basin experienced greater water table fluctuations and a higher average water level $(7.3 \mathrm{~cm}$ above peat surface). There were significant winter and spring floodings in the upper basin, with water tables peaking more than $20 \mathrm{~cm}$ above peat surface (Fig. 7). Fluctuations of the mire surface were registered as only $2-4 \mathrm{~cm}$ during the three-year study period.

The two basins differed in groundwater composition: although groundwater is rich in $\mathrm{Ca}^{2+}$ and $\mathrm{Mg}^{2+}$ ions in both sites, their concentrations are higher in the upper basin (B), while high total $\mathrm{Fe}$ concentrations distinguish the lower basin (A) (Fig. 8, Fig. 9). The higher concentrations of $\mathrm{NO}^{3-}$ (and relatively also $\mathrm{SO}_{4}{ }^{2-}$ and $\mathrm{Ca}^{2+}$ ) and lower carbonate hardness distinguish the river water.

The upper basin (B) is richer in species of Caricion davallianae alkaline fens (e.g. Campylium stellatum, Limprichtia cossonii, Carex lepidocarpa) and distinguishable with a sparse cover of shrubs and trees (Salix cinerea, S. pentandra, S. rosmarinifolia, Pinus sylvestris (Fig. 10) as well as Betula pubescens). In the rich fens of area B species like Tomentypnum nitens, Hamatocaulis vernicosus, Carex rostrata and Festuca rubra are prominent.

Standing vascular plant biomass confidence intervals overlap for areas A and B (the difference is not significant). Significant differences were found for $\mathrm{P}$ concentrations in the plant biomass and $\mathrm{N}: \mathrm{P}$ ratio (Fig. 11). N:P ratio values in

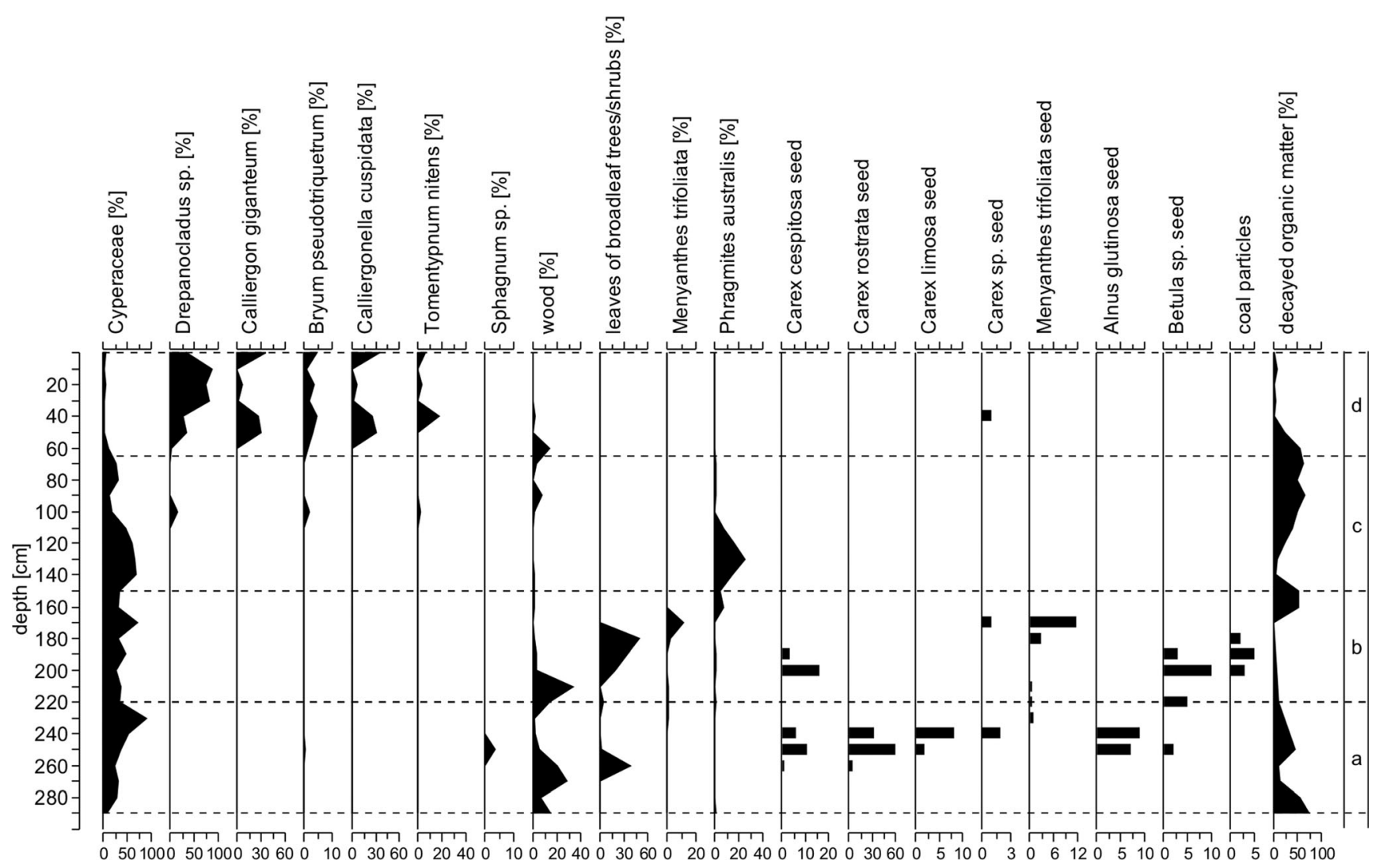

Fig. 4 Main plant macroremains in the profile B (upper basin) 


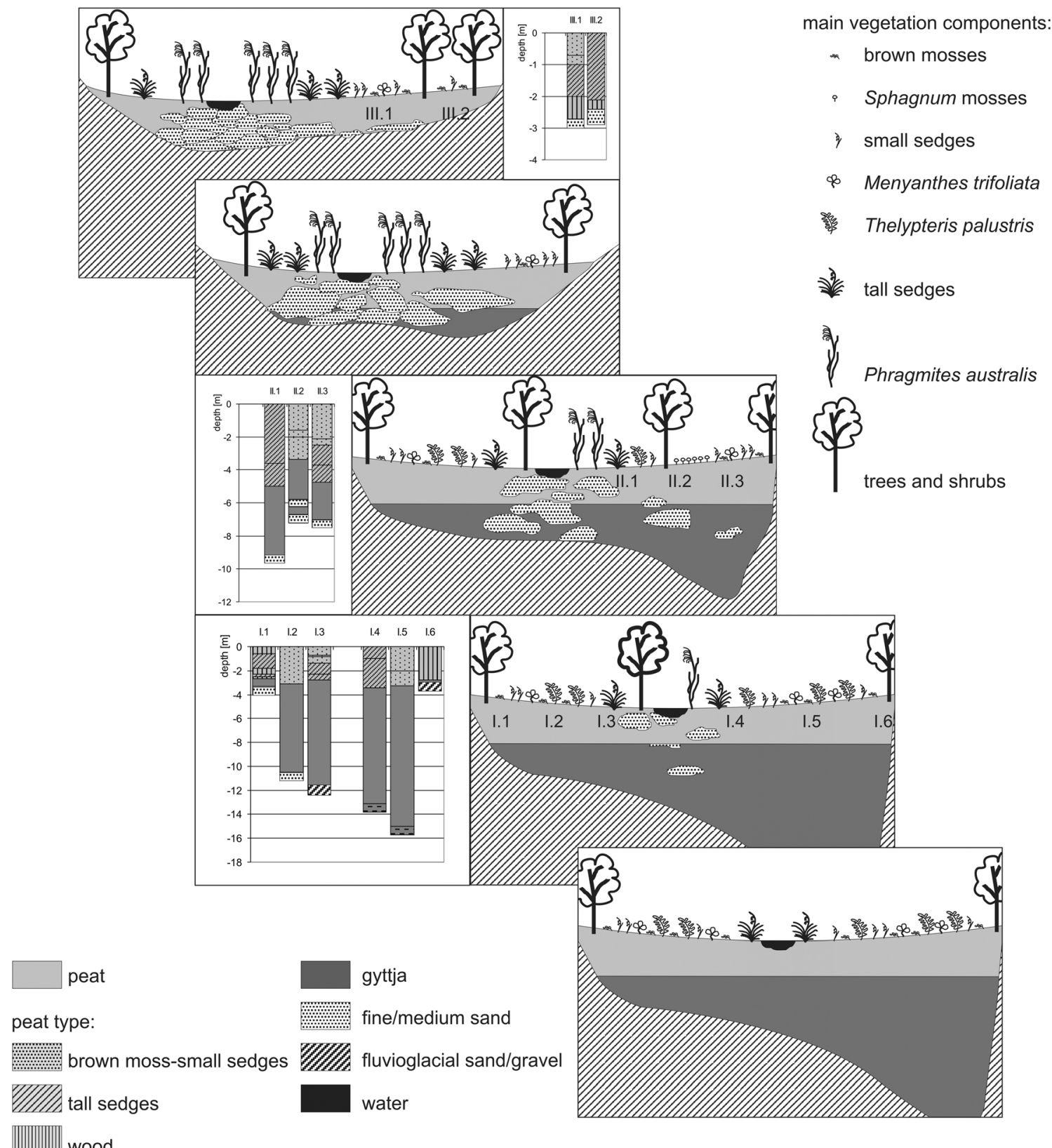

Fig. 5 Cross-sections of the Rospuda mire - a simplified extrapolation from peat profile analysis and deep cores in the riverbed analysis. I.1, I.2, ... III. 2 - peat profile along transects; for locations of the profiles -

the lower basin (A) were significantly higher (mean 14.2, $95 \%$ CI: 13.5-14.8) than in the upper basin (B) (mean 7.2, $95 \%$ CI: 6.0-8.4), which is mainly caused by different $\mathrm{P}$ concentrations (A: mean $1.53 \mathrm{mg} \mathrm{g}^{-1}, 95 \% \mathrm{CI}: 1.28$ $1.76 \mathrm{mg} \mathrm{g}^{-1}$; B: mean $0.83 \mathrm{mg} \mathrm{g}^{-1}, 95 \% \mathrm{CI}: 0.76-$ $0.89 \mathrm{mg} \mathrm{g}^{-1}$ ). Differences in $\mathrm{N}$ (A: mean $10.60 \mathrm{mg} \mathrm{g}^{-1}$, $95 \%$ CI: $9.83-11.38 \mathrm{mg} \mathrm{g}^{-1}$; B: mean $11.75 \mathrm{mg} \mathrm{g}^{-1}, 95 \%$ CI: $10.79-12.71 \mathrm{mg} \mathrm{g}^{-1}$ ) and $\mathrm{K}$ (A: mean $8.52 \mathrm{mg} \mathrm{g}^{-1}, 95 \%$ CI: $7.15-9.89 \mathrm{mg} \mathrm{g}^{-1}$; B: mean $8.12 \mathrm{mg} \mathrm{g}^{-1}, 95 \%$ CI: 7.73$8.51 \mathrm{mg} \mathrm{g}^{-1}$ ) concentrations were not significant between basins. compare Fig. 1; slope of a mire is presented schematically, for more detailed mire surface levelling, see Jabłońska et al (2011)

\section{Discussion}

The development of the two different parts of the Rospuda mire, which are at present both covered by small sedge-brown moss communities, differed substantially. These differences were related to the geomorphological features of the mineral base, as schematically outlined in Fig. 6. In the upper basin (B) peat formation started on sands from the river delta system. At the beginning, vegetation was dominated by (sparse) tall sedge communities, but also scattered trees (Betula, Alnus) could establish, so the peat was, at least periodically, 

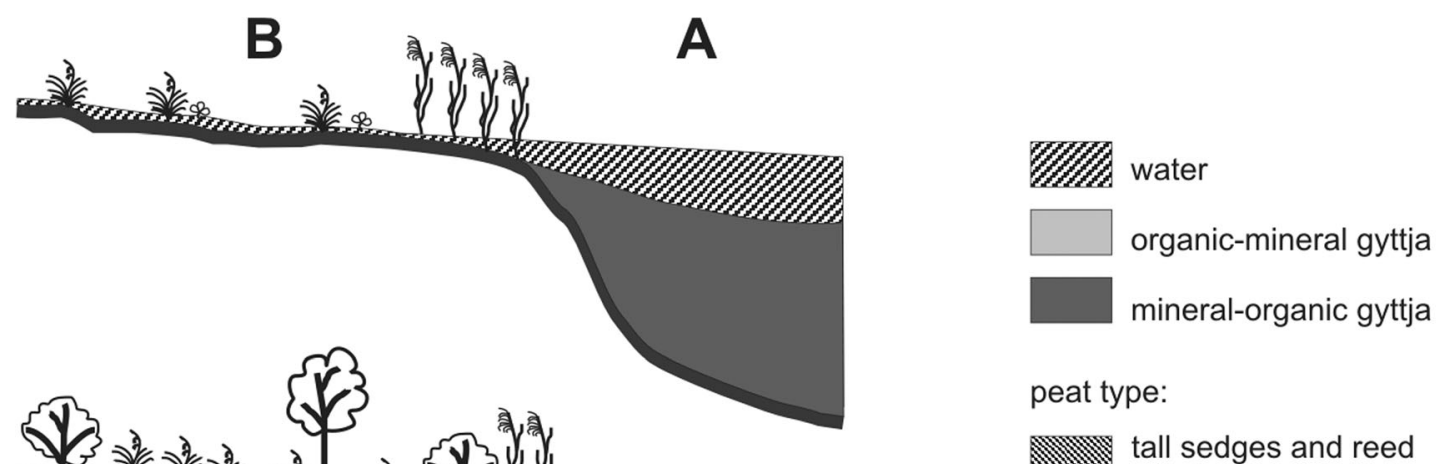

peat type:

tall sedges and reed
III!I!l wood
Sphagnum mosses

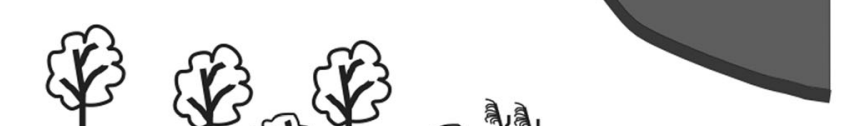

a | m main vegetation components:

aquatic macrophytes

* brown mosses

is small sedges

os Menyanthes trifoliata

Thelypteris palustris
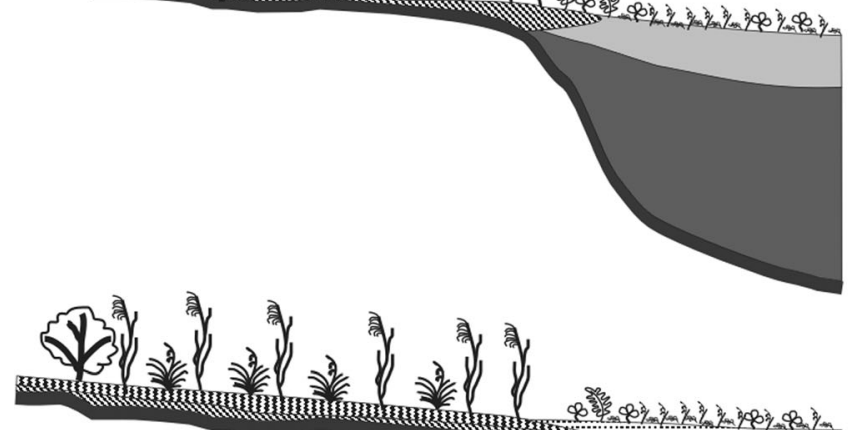

b
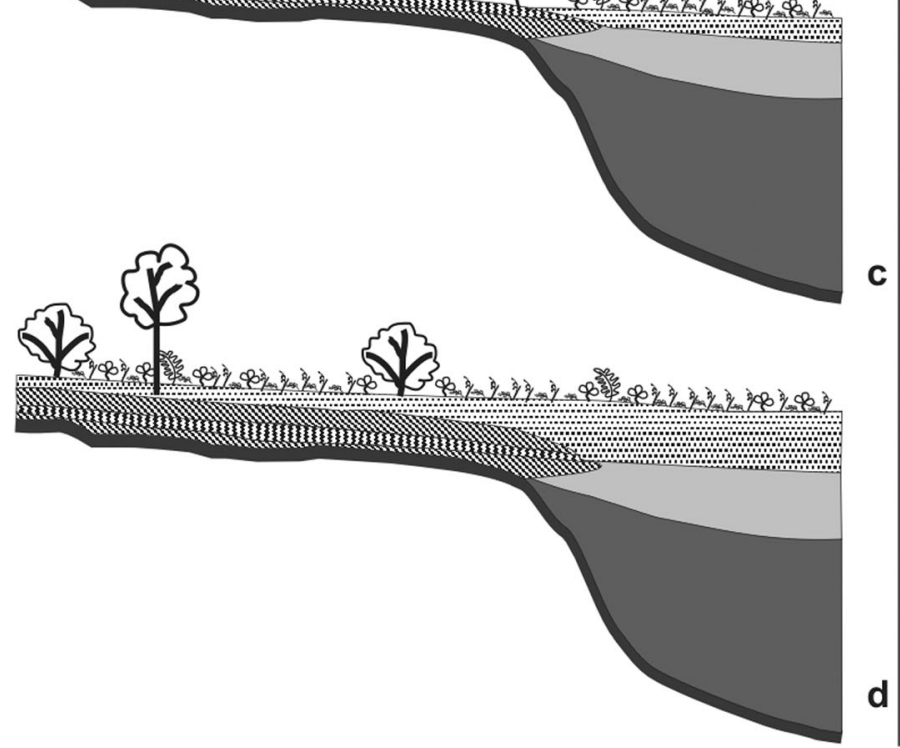

d

Fig. 6 Interpretation of the Rospuda mire vegetation development; phases a, b, c, d correspond to the zones in Fig. 4, phases m, n correspond to the zones in Fig. 3; slope of a mire is presented schematically, for more detailed mire surface levelling, see Jabłońska et al (2011)

sufficiently dry to allow growth of trees. The stable ground with underlying sands may also have supported tree growth. Later on, either reed beds, probably during wetter periods, or shrubs and trees, probably during dryer periods, developed. The peat was compacted and relatively decomposed already from the beginning of mire development. This has probably 
Fig. 7 Hydrographs of the water level for a period of 2007-2009, within two basins of the Rospuda mire; ground level is marked as 0 ; diver readings were transform from the absolute to the relative values by taking away the absolute values of ground level; A - lower basin, B - upper basin); dates with levelling measurements are marked with asterisk

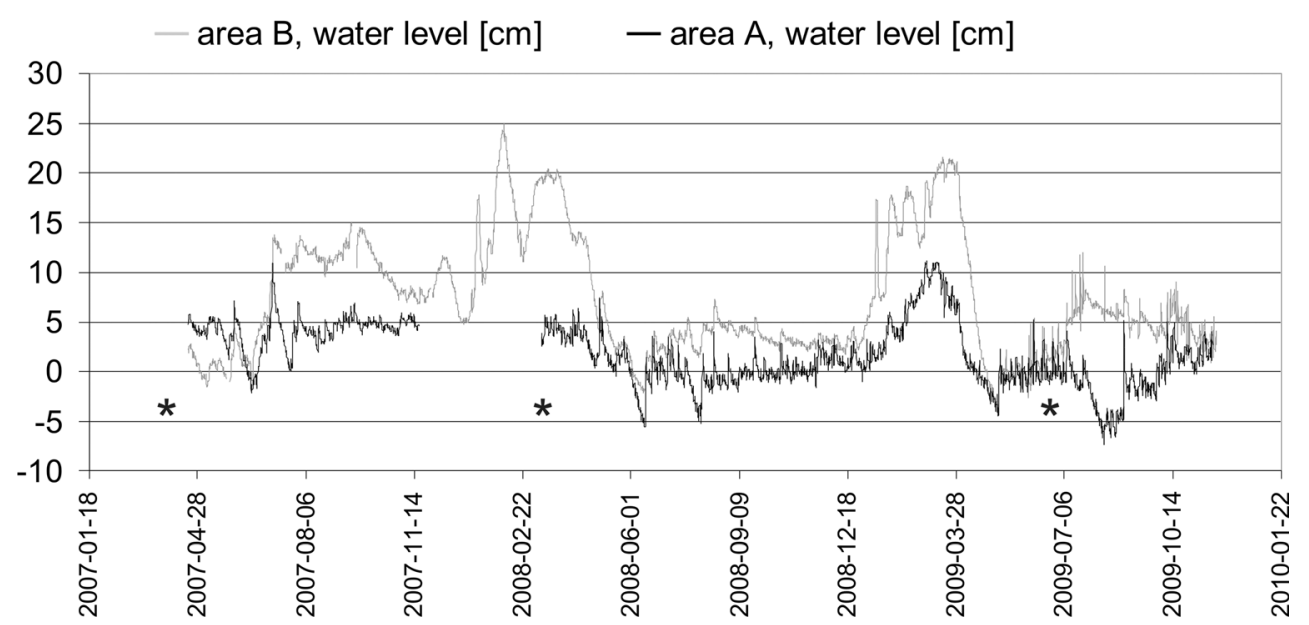

caused a positive feedback: because the peat surface could not oscillate with water level movements, reedbeds (in wetter periods) or trees and shrubs (in drier periods) developed, inducing further peat decomposition due to increased evapotranspiration and oxygen transport to the root zone.

In the lower basin (A), peat development started by terrestrialization of a glacial lake. Brown moss-small sedge communities, with floristic composition similar to that of today (zone $n$ ), established shortly after terrestrialization of the lake (zone m). These communities remained very stable

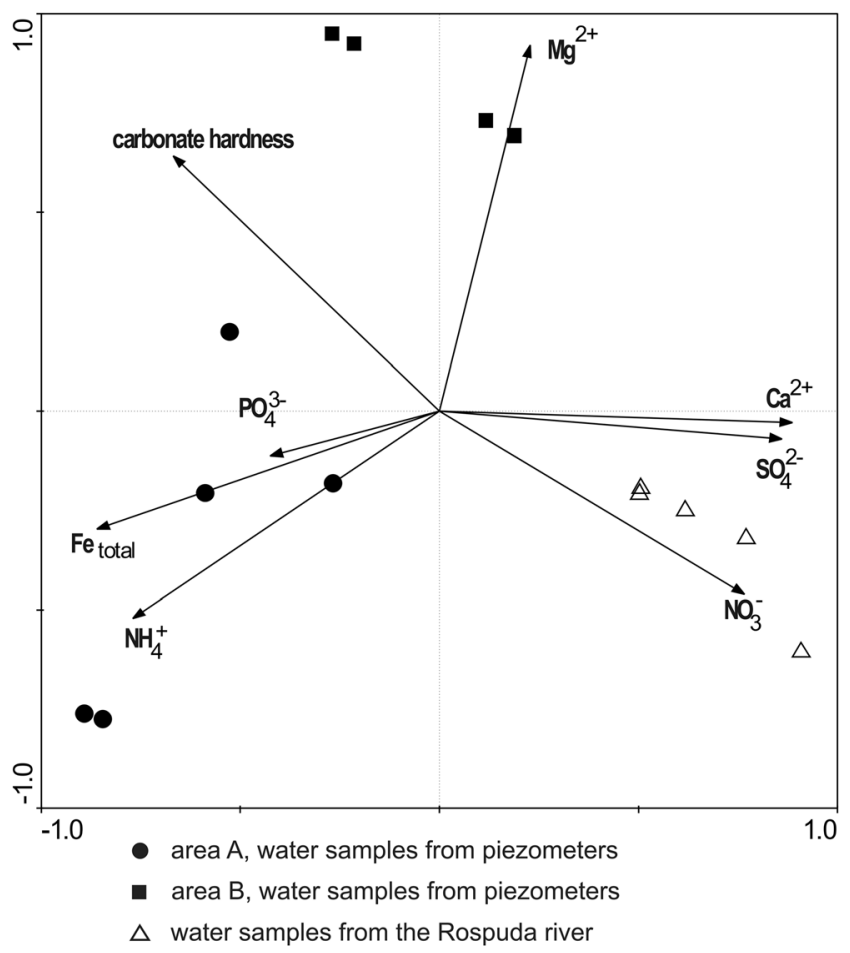

Fig. 8 Principal Component Analysis of mean water parameters of water samples from area A (lower basin) and B (upper basin) in the Rospuda valley and river water samples; eigenvalues: I - 0.718, II - 0.202, III 0.062 , IV -0.010 ; correlations between water parameters and origin of a sample: I-0.539, II -0.135 , III -0.755 , IV -0.117 ; axes 1 and 3 are shown for a long time and probably subsequently expanded to the upper basin (Fig. 6). Stable hydrological conditions with continuous groundwater supply, (persisting until today, which is expressed by groundwater level remaining near the ground surface during three years of measurements (Fig. 7)), allowed for the development of little-decomposed peat with a loose structure. With increasing peat thickness, the ability of the peat surface to oscillate with changing water levels could have increased further, limiting possible effects of climate fluctuations on the mire ecosystem. Our measurements did not show pronounced mire surface oscillations, perhaps because no pronounced dry period occurred during the study period.

In the upper basin, episodes of spring flooding reaching the zone of brown moss-small sedge vegetation were observed (Fig. 7), with the highest water levels of $25 \mathrm{~cm}$ above peat surface, whereas in the lower basin floods were restricted to a narrow riverine zone, not reaching the brown moss-small sedge communities (cf. Jabłońska et al 2011). This difference can, firstly, be explained by the fact that brown moss-small sedge fens in the lower basin are located further away from the river and elevated above its water level (because of the larger valley width and a steeper inclination of the mire, $\mathrm{cf}$. Jabłońska et al 2011, Fig. 4). Secondly, different structure, decomposition rate and compaction of the peats in the two valley parts additionally contribute to the buffering of water level fluctuations, indicating how vegetation, via its peatforming potential, interplays with the landscape settings in controlling the local hydrological processes. As no pronounced dry period occurred during 2007-2009, we have not recorded significant drops of the water level below the mire surface in the upper basin, however we observed such situations several times during very dry periods in other years (this in contrast to the lower basin, where the water level was constantly more or less equal with the mire surface). The hydrological instability of the upper basin could have contributed to the different nutrient status of this area as compared to the lower basin. 

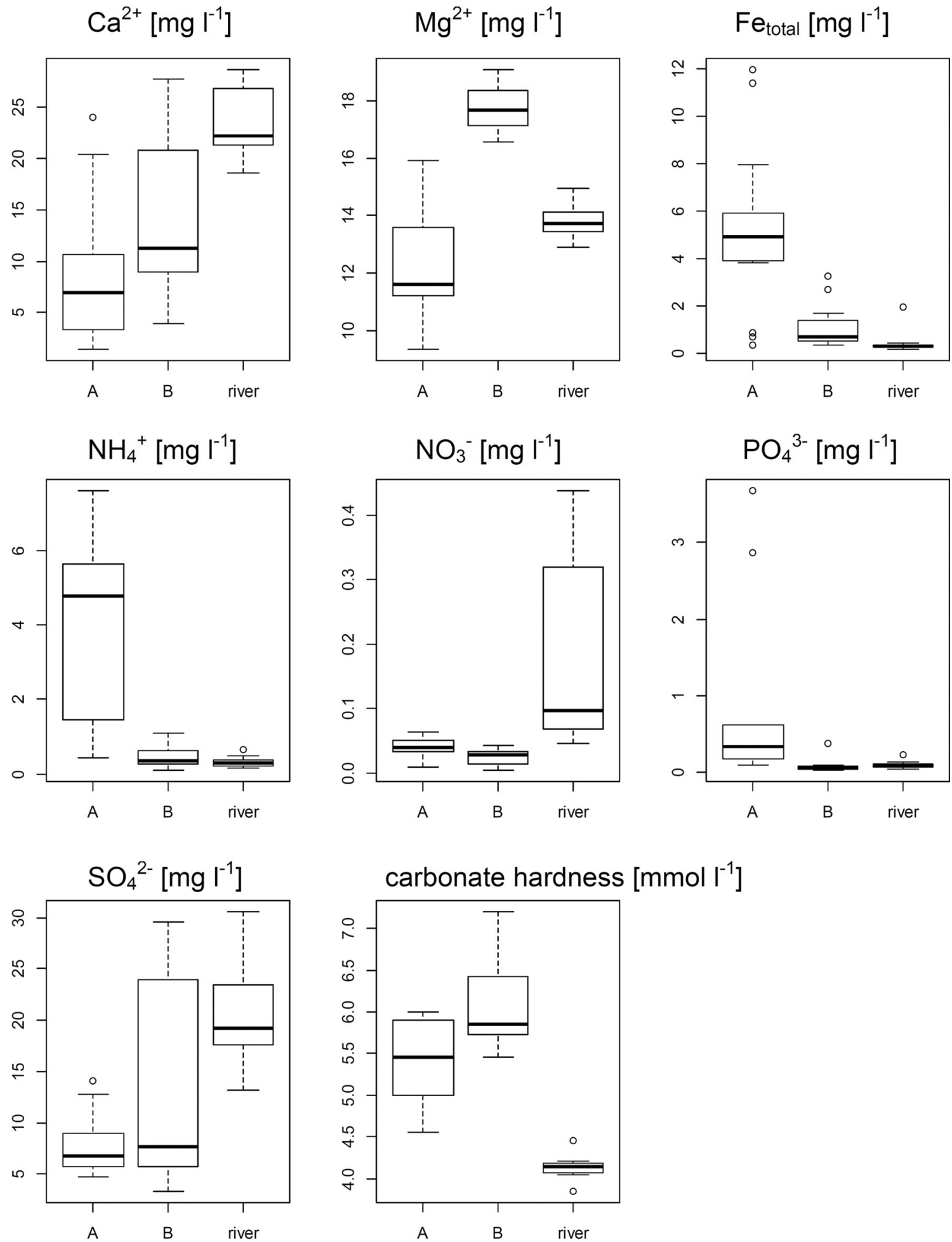

Fig. 9 Comparisons of the chemical properties of water samples from piezometers located in area A (lower basin) and B (upper basin) in the Rospuda valley and river water samples; medians, interquartile ranges

IQR (boxes), ranges IQR $+2 * 1.5 \mathrm{IQR}$ (whiskers) as well as minimum and maximum values (circles) are shown; $\mathrm{n}=15$ ( 5 sites $\mathrm{x} 3$ measurements) for area $A$ and river, $n=12$ ( 4 sites $\times 3$ measurements) for area $B$

Fen vegetation in the upper basin (B) has a higher N:P ratio, suggesting N/P co-limitation (Güsewell and Koerselman 2002; Wassen et al 2005), whereas N-limitation was found in the lower basin (A). Neither in the upper nor in the lower basin $\mathrm{K}-$

limitation occurred (Olde Venterink et al 2003). Floristic differences between small sedge-brown moss vegetation in the two basins correspond to the main division of rich fen vegetation in NE Poland described by Pawlikowski et al (2013). The cited 


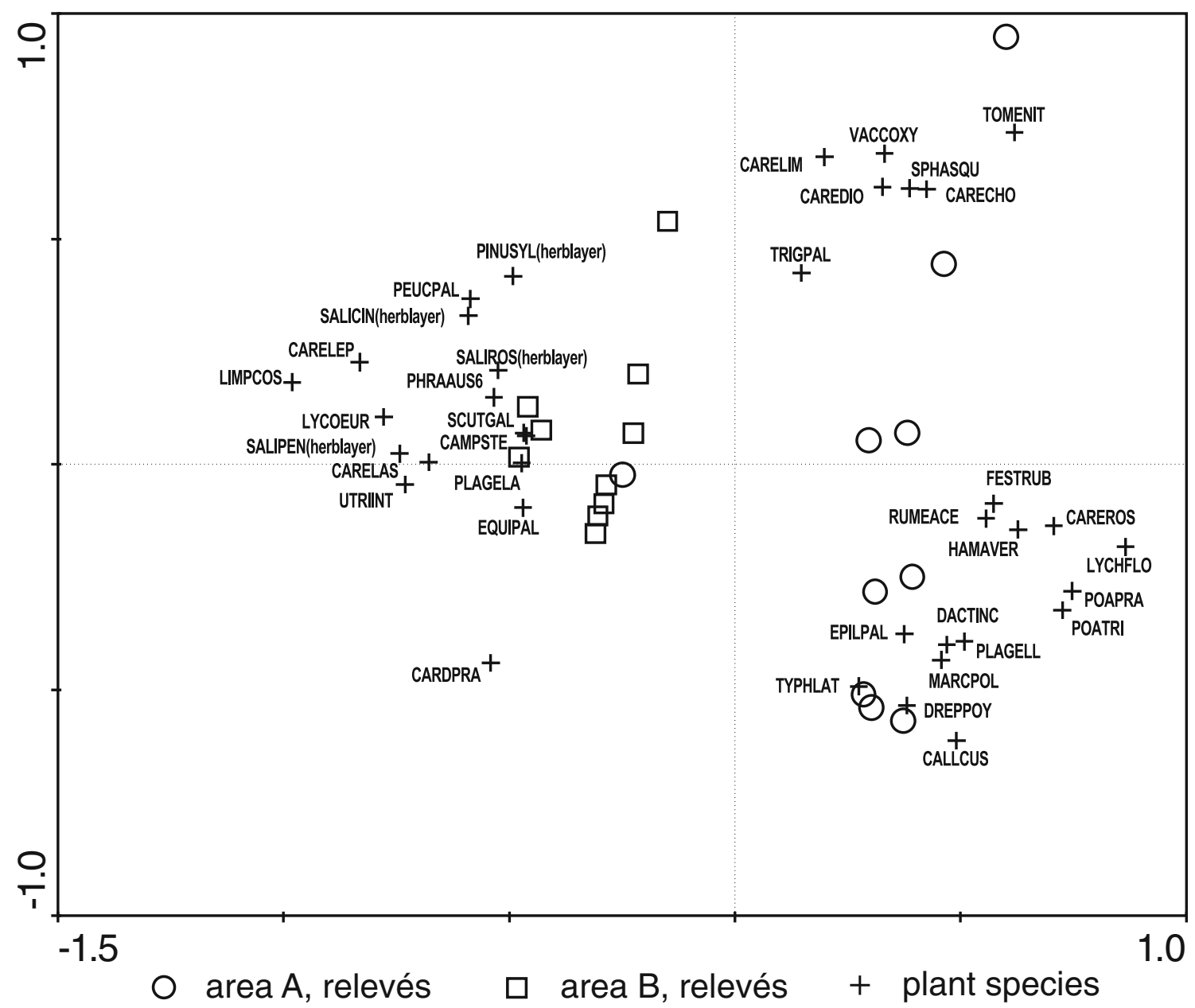

Fig. 10 Principal Component Analysis of vegetation relevés from open brown moss-sedge fens in area A (lower basin) and B (upper basin) in the Rospuda valley; eigenvalues: I -0.515 , II -0.157 , III -0.098 , IV -0.075 ; axes 1 and 2 are shown

authors found lower N:P ratios (and subsequent N-limitationOlde Venterink et al 2003) in so called 'non-Caricetalia davallianae fens' (similar to those in the lower basin of Rospuda) and higher $\mathrm{N}: \mathrm{P}$ ratios (frequent P-limitation) in Caricetalia davallianae fens (similar to those developed in the upper basin).
We see several possible explanations of the differences in $\mathrm{N}: \mathrm{P}$ ratios between the two Rospuda basins that we studied, which all are related to differences in water level fluctuation patterns. First, P-(co)limitation might be enhanced by spring floods in the upper basin. The direct effect of spring flooding relates to the import of nitrates $\left(\mathrm{NO}_{3}^{-}\right)$, which is one of the few
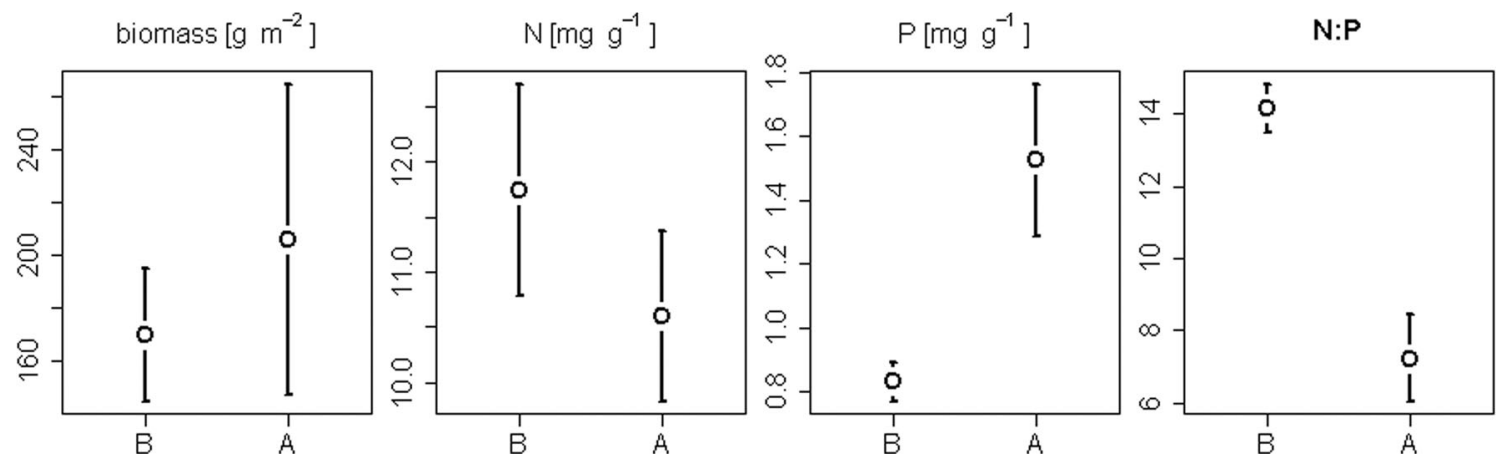

Fig. 11 Comparisons between standing biomass of vascular plants, $\mathrm{N}$ and $\mathrm{P}$ concentrations in plant biomass and $\mathrm{N}: \mathrm{P}$ ratio in area $\mathrm{A}$ (lower basin) and $\mathrm{B}$ (upper basin) in the Rospuda valley; means and $95 \%$ confidence intervals are shown 
parameters distinguishing river water from groundwater in our area. The highest nitrate concentrations (although still very low compared to agriculturally polluted rivers) were noted in May, when river water contained $0.4 \mathrm{mg} \mathrm{NO}_{3}{ }^{-1}{ }^{-1}$ (compared to $0.05 \mathrm{mg} \mathrm{l}^{-1}$ in groundwater). River floods may also enhance $\mathrm{P}$ limitation indirectly due to rising the redox potential. Oxygen rich river water may cause sorption of phosphates on iron hydroxides, which then can be flushed back to the river in a suspended form, when water returns to the river (this occurs quickly as surface runoff). The same may hold for phosphate precipitation with $\mathrm{Ca}^{2+}$, which is relatively more abundant in river water and groundwater in the upper basin (B) than in the lower basin. P precipitation may further be enhanced by the relatively high water $\mathrm{SO}_{4}{ }^{2-}$ concentrations in the upper basin and in the river water: during "normal" conditions pyrite $\left(\mathrm{FeS}_{2}\right)$ may be formed in the surface layer of the mire, which during floods with oxic river water may be oxidised, stimulating P-binding (Grootjans et al 2006). Moreover, analogous processes of $\mathrm{P}$-precipitation could occur during dry years, when water level drops below peat surface and redox rises in effect of soil aeration. In such dry years, nitrogen input from peat decomposition may further raise the availability of $\mathrm{N}$ relative to $\mathrm{P}$, which would become immobilised by iron hydroxides. In the lower basin, where water level stayed close to the surface during the whole season, $\mathrm{N}$ and $\mathrm{P}$ inputs from peat mineralisation are very low, whereas low redox potential make P freely available (cf. Cusell et al 2013).

The observation that the flooded fen has a lower P-availability is in line with the results of Olde Venterink et al (2009) from the Biebrza valley, where floodplain fens appeared to be $\mathrm{P}$-limited, while non-flooded fens were $\mathrm{N}$-limited. In the natural Siberian percolation fens of the $\mathrm{Ob}$ valley where occasionally occurring floods used to be a natural phenomenon, P-limitation was also found (Schipper et al 2007).

Primary productivity under $\mathrm{P}-$ (co)limited conditions is redox-dependent, meaning that oxidation of the upper soil layers may decrease productivity, whereas stagnation of anoxic water will increase productivity. This indicates that mires are less stable under $\mathrm{P}$-limited conditions than under $\mathrm{N}-$ limitation. In the upper basin, where peat developed on mineral ground, this effect of low $\mathrm{P}$-availability probably interacts with other mechanisms, e.g. enhanced establishment of trees during drier years (thus avoiding soil anoxia) or reed (Phragmites australis) in wet years. Our results indeed show higher abundance of shrubs and trees, as well as reed in the upper basin (Fig. 10).

A previous study by Jabłońska et al (2011) showed, that the chemical composition of subsurface water (sampled from shallower, $0.5 \mathrm{~m}$-deep, piezometers) is quite uniform within the whole Rospuda mire and is not especially useful for distinguishing vegetation types. In the present study we analysed water from the bottom peat layer (in order to minimise influence of external factors), revealing that the two basins may be fed by groundwater from two different aquifers (Fig. 8, Fig. 9). The water is rich in $\mathrm{Fe}$ in the lower basin, while in the upper one water is rich in $\mathrm{Mg} 2+$ and has slightly higher $\mathrm{Ca}^{2+}$ concentrations than in the lower basin. These differences in groundwater composition do not significantly alter vegetation composition in the two basins and allows for the development of similar vegetation types. However those differences in water chemistry may have a marked effect on the long-term stability of fen vegetation patterns.

It is notable that $\mathrm{Ca}^{2+}$ concentrations in the Rospuda mire are much lower compared to those observed in brown moss rich fens in continental Western and Central Europe, e.g. in the Netherlands (Wassen \& Barendregt 1992, Kooijman 2012) and Czech Republic and Slovakia (Hájek et al 2002). One explanation can pertain to the fact that rich fens in areas with high $\mathrm{N}$ deposition need higher $\mathrm{Ca}^{2+}$ concentrations to reach similar pH values. Kooijman (2012) revealed that habitats of alkaline fen specialists among brown mosses are more acidic in areas with low $\mathrm{N}$-deposition (including eastern Poland) than in 'polluted' fens of the Netherlands. Higher $\mathrm{Ca}^{2+}$ concentrations in the upper Rospuda basin may contribute to higher $\mathrm{P}$ precipitation irrespective of redox potential. High Fe concentrations in the lower basin would only lead to $\mathrm{P}$ binding in case of oxic conditions (water level dropping or flooding with oxic water), which is not the case in that part of the valley, due to the strong hydrological buffering capacity of the fen.

Our interpretation suggests that differences in nutrient limitation between fen vegetation are determined by geological and eco-hydrological conditions. Landscape settings have not been considered before as key factors explaining the stability of percolation fens, although their importance for fen development has been acknowledged by many authors (e.g. Kulczyński 1949; Brinson 1993; Wheeler and Proctor 2000; Joosten and Clarke 2002, Grootjans et al 2006). Our study shows unambiguously that an adequate characterization of the subsurface geology seems necessary to understand water fluxes in a mire. This was shown before by e. g. AlmquistJacobson and Foster (1995), Bendjoudi et al (2002), Kurtz et al (2007), but it has hardly been taken into account in modelling of mire dynamics (e.g. Hilbert et al 2000). Due to specific landscape settings some fens are more likely to remain stable than others. The information about these settings usually remains hidden under peat deposits, being outside the reach of palaeobotanical corings. Few researchers have taken into account the starting point of fen development when analyzing its history (but see e.g. Michaelis 2002). We showed that the geological background is largely responsible also for revealed differences in chemical composition of groundwater feeding the two Rospuda basins, e.g. due to the access to different groundwater aquifers (Fig. 8). We hypothesize that differences in mire water chemistry revealed in comparative 
research are frequently caused by the differences in geological and landscape settings.

Compared to the Rospuda fens, the percolation fens of the neighbouring upper Biebrza valley are much more vulnerable to shrub and tree encroachment, which might perhaps be explained by more shallow (up to $3 \mathrm{~m}$ (Oświt 1991)) and thinner gyttja layers (underlying c. $18 \%$ of the peat area (Żurek 1975)) but also may result from different history of human impact in the Biebrza fens (local moderate drainage and centuries of mowing (Bartoszuk and Kotowski 2009). The Siberian percolation fens of the $\mathrm{Ob}$ valley that lack human pressure remain treeless being underlain by only shallow layers of gyttja. They have developed several meters of homogenous moss peat directly on river deposits (just as in the upper Rospuda basin), probably fostered by intensive groundwater seepage on the valley edge (Schipper et al 2007). Although it is risky to compare such distant systems, developed under different climatic conditions, there are several additional factors that could have made the $\mathrm{Ob}$ system stable, such as its large surface area and large catchment with low human impact on its hydrology. Extensive fen systems sustained by large hydrological systems are less vulnerable to local drainage than small ones (Grootjans et al 2006).

We conclude, that the geological background and geomorphological landscape settings of the percolation fen strongly influence its long-term development and stability, controlling local eco-hydrological regime and nutrient cycling. Long-term persistence of a mire as an open sedge-moss fen can be enhanced by a number of different mechanisms, operating at the landscape scale of the catchment, as well as the local scale at the interface between water, peat, microbial live and vegetation. The subsurface geological settings of the mire basin are likely to influence all mechanisms of the latter category, the most stable systems developing probably in sites, where different negative feedback mechanisms, that limit oxygen and nutrient supply for plants, operate simultaneously.

\begin{abstract}
Acknowledgments We would like to thank Yuki Fujita for helping with biomass analyses and two anonymous reviewers for their helpful comments that improved the manuscript. The research was financed by the Polish Ministry of Science and Higher Education Grant no. N304 010 31/0414. The article preparation was finalized in Biological and Chemical Research Centre of the University of Warsaw.
\end{abstract}

Open Access This article is distributed under the terms of the Creative Commons Attribution License which permits any use, distribution, and reproduction in any medium, provided the original author(s) and the source are credited.

\section{References}

Allen SE (1989) Chemical Analysis of Ecological Materials. 2nd edition, Blackwell Scientific Publications, Oxford
Almquist-Jacobson H, Foster DR (1995) Toward an integrated model for raised-bog development: theory and field evidence. Ecology 76: 2503-2516

Bartoszuk H, Kotowski W (2009) Large wetlands of the Biebrza Valley, Poland. In: Veen P, Jefferson R, de Smidt J, van der Straaten J (eds) Grasslands of Europe of high nature value. KNNV Publishing, Zeist, pp 84-94

Beaulieu-Audy V, Garneau M, Richard PJH, Asnong H (2009) Holocene palaeoecological reconstruction of three boreal peatlands in the $\mathrm{La}$ Grande Rivière region, Québec, Canada. The Holocene 19(3):459-476

Beijerink W (1976) Zadenatlas der Nederlandsche Flora. Backhuys and Meesters, Amsterdam

Belyea LR, Baird AJ (2006) Beyond "the limits to peat bog growth": cross-scale feedback in peatland development. Ecol Monogr 76(3): 299-322

Bendjoudi H, Wang P, Guérin R, Pastre JF (2002) Riparian wetlands of the middle reach of the Seine river (France): historical development, investigation and present hydrologic functioning. J Hydrol 263: $131-155$

Ber A (2000) Plejstocen Polski północnowschodniej w nawiązaniu do głębszego podłoża i obszarów sąsiednich. Prace PIG 170:1-89

Berggren G (1969) Atlas of seeds and small fruits of NorthwestEuropean plant species. Part 2. Cyperaceae. Swedish Natural Science Research Council, Stockholm

Bertsch K (1941) Früchte und Samen. Ein Bestimmungsbuch zur Pflanzenkunde der vorgeschichtlichen Zeit. Verlag Ferdinand Enke, Stuttgart

Braun-Blanquet J (1951) Pflanzensoziologie. 2. Aufl. Springer, Wien

Bridgham SD, Pastor J, Dewey B, Weltzin JF, Updegraff K (2008) Rapid carbon response of peatlands to climate change. Ecology 89(11): 3041-3048

Brinson MM (1993) A Hydrogeomorphic Classification for Wetlands. Wetlands Research Program Technical Report. US Army Corps of Engineers, Washington

Chormański J (2008) Zastosowanie techniki GPS RTK w pomiarach rzędnych zwierciadła wody podczas zalewu rzecznego. Zesz Probl Postep Nauk Roln 532:67-75

Cusell C, Lamers LPM, van Wirdum G, Kooijman A (2013) Impacts of water level fluctuation on mesotrophic rich fens: acidification vs. eutrophication. J Appl Ecol 50:998-1009

Dise NB (2009) Peatland response to global change. Science 326:810-811

Eppinga MB, Rietkerk M, Wassen MJ, De Ruiter PC (2009) Linking habitat modification to catastrophic shifts and vegetation patterns in bogs. Plant Ecol 200:53-68

Granath G, Strengbom J, Rydin H (2010) Rapid ecosystem shifts in peatlands: linking plant physiology and succession. Ecology 91: 3047-3056

Grootjans AP, Adema EB, Bleuten W, Joosten H, Madaras M, Janáková M (2006) Hydrological landscape settings of baserich fen mires and fen meadows: an overview. Appl Veg Sci 9:175-184

Grosse-Brauckman G (1972) Pflanzliche Makrofossilien mitteleuropäischer Torfe. I Gewebereste krautiger Pflanzen und ihre Merkmale 2:19-55

Grosse-Brauckman G, Streitz B (1992) Pflanzliche Makrofossilien mitteleuropäischer Torfe. III. Früchte, Samen und einige Gewebe. Telma 22:53-102

Güsewell S, Koerselman W (2002) Variation in nitrogen and phosphorus concentrations of wetland plants. Perspect Plant Ecol Evol Syst 5(1): 37-61

Hájek M, Hekera P, Hájková P (2002) Spring fen vegetation and water chemistry in the Western Carpathian flysch zone. Folia Geobotanica 37:205-224

Hájková P, Grootjans A, Lamentowicz M, Rybníčková E, Madras M, Opravilová V, Michaelis D, Hájek M, Joosten H, Wołejko L (2012) How a Sphagnum fuscum-dominated bog changed into a calcareous 
fen: the unique Holocene history of a Slovak spring-fed mire. J Quat Sci 27(3):233-243

Hilbert D, Roulet WN, Moore T (2000) Modelling and analysis of peatlands as dynamical systems. J Ecol 88:230-242

Hughes PDM, Barber KE (2004) Contrasting pathways to ombrotrophy in three raised bogs from Ireland and Cumbria, England. The Holocene 14:65-77

Ives AR, Carpenter SR (2007) Stability and diversity of ecosystems. Science 317(5834):58-62

Jabłońska E, Pawlikowski P, Jarzombkowski F, Chormański J, Okruszko T, Kłosowski S (2011) Importance of water level dynamics for vegetation patterns in a natural percolation mire (Rospuda fen, NE Poland). Hydrobiologia 674(1):105-117

Joosten H, Clarke D (2002) Wise use of mires and peatlands-Background and principles including a framework for decision-making. International Mire Conservation Group/International Peat Society, Saarijärvi

Juggins S (2003) $C^{2}$ User guide. Software for ecological and palaeoecological data analysis and visualisation. University of Newcastle, Newcastle

Kooijman AM (2012) 'Poor rich fen mosses': atmospheric Ndeposition and $\mathrm{P}$-eutrophication in base-rich fens. Lindbergia 35: $42-52$

Kulczyński S (1949) Peat bogs of Polesie. Mémoires de l'Académie Polonaise des Sciences et des Lettres. Bulletin des Sciences Naturelles B: Sci Nat 15:1-359

Kurtz AMD, Bahr JM, Carpenter QJ, Hunt RJ (2007) The importance of subsurface geology for water source and vegetation communities in Cherokee Marsh, Wisconsin. Wetlands 27(1):189-202

Michaelis D (2001) Schlüssel zur Bestimmung von Braunmoosen aus Torfen anhand einzelner Blättchen. Telma 31:79-104

Michaelis D (2002) Die spät-und nacheiszeitliche Entwicklung der natürlichen Vegetation von Durchströmungsmooren in Mecklenburg-Vorpommern am Beispiel der Recknitz. Dissertationes Botanicae 365:1-188

Morris PJ, Balyea LR, Baird AJ (2011) Ecohydrological feedbacks in peatland development: a theoretical modelling study. J Ecol 99: $1190-1201$

Nilsson Ö, Hjelmquist H (1967) Studies in the nutlet structure of south Scandinavian species of Carex. Bot Notiser 120:460-485

Olde Venterink H, Wassen MJ, Verkroost AWM, de Ruiter PC (2003) Species richness-productivity patterns differ between N-, P-and Klimited wetlands. Ecology 84:2191-2199

Olde Venterink H, Kardel I, Kotowski W, Peeters W, Wassen MJ (2009) Long-term effects of drainage and hay-removal on nutrient dynamic and limitation in the Biebrza mires, Poland. Biogeochemistry 93: 235-252

Oświt J (1991) Budowa, geneza i rozwój torfowisk pradolinnych Biebrzy. Zesz Probl Postep Nauk Roln 372:185-217
Pawlikowski P, Abramczyk K, Szczepaniuk A, Kozub Ł (2013) Nitrogen:phosphorus ratio as the main ecological determinant of the differences in the species composition of brown-moss rich fens in north-eastern Poland. Preslia 85:349-367

Scheffer M, Carpenter S, Foley JA, Folke C, Walker B (2001) Catastrophic Shifts in Ecosystems. Nature 413(6856):591-9

Schipper AM, Zeefat R, Tanneberger F, van Zuidam JP, Hahne W, Schep SA, Loos S, Bleuten W, Joosten H, Lapshina ED, Wassen MJ (2007) Vegetation characteristics and eco-hydrological processes in a pristine mire in the Ob River valley (Western Siberia). Plant Ecol 193: $131-145$

Schröder C, Thiele A, Wang S, Bu Z, Joosten H (2007) Hani-Mire-A percolation mire in Northeast China. Peatlands International 2:21-24

Smith AJE (1980) The Moss Flora of Britain and Ireland. Cambridge University Press, Cambridge

Succow M, Joosten H (2001) Landschaftsökologische Moorkunde. Auflage 2. E. Schweizerbart'sche Verlagsbuchhandlung, Stuttgart

Ter Braak CJF, Šmilauer P (1998) CANOCO Reference Manual and User's Guide to Canoco for Windows. Software for Cannonical Community Ordination (version 4). Centre for Biometry Wageningen (Wageningen, NL) and Microcomputer Power Ithaca, New York

The R development Team (2010) R: a language and environment for statistical computing. Foundation for Statistical Computing, Vienna

Tobolski K (2000) Przewodnik do oznaczania torfów i osadów jeziornych. Vademecum Geobotanikum 2. Wydawnictwo Naukowe PWN, Warszawa

Van Diggelen R, Middleton B, Bakker J, Grootjans A, Wassen M (2006) Fens and floodplains of the temperate zone: Present status, threats, conservation and restoration. Appl Veg Sci 9:157-162

Van Duren IC, Pegtel DM (2000) Nutrient limitations in wet, drained and rewetted fen meadows: evaluation of methods and results. Plant Soil 220(1-2):35-47

Wassen MJ, Barendregt A (1992) Topographic position and water chemistry of fens in a Dutch river plain. J Veg Sci 3:447-456

Wassen MJ, Olde Venterink H (2006) N and P fluxes in European fens and floodplains. Appl Veg Sci 9:213-222

Wassen MJ, Olde Venterink H, Lapshina ED, Tanneberger F (2005) Endangered plants persist under phosphorus limitation. Nature 437(7058):547-550

Wheeler BD, Proctor CF (2000) Ecological gradients, subdivisions and terminology of north-west European mires. J Ecol 88ccc:187-203

Wysocka A (1992) Osady, geneza i ewolucja jeziora Garbaś, Pojezierze Suwalskie. Prz Geol 42(5):308-312

Żurek S (1975) Geneza zabagnienia pradoliny Biebrzy. Prace Geograficzne PAN 110:1-107

Żurek S, Michczyńska DJ, Pazdur A (2002) Time record of palaeohydrologic changes in the development of mires during the Late Glacial and Holocene, North Podlasie Lowland and Holy Cross Mts. Geochronometria 21:109-118 